\title{
Effects of feeding rumen-degradable valine on milk production in late-lactating dairy cows
}

\author{
Kayla M. Hultquist and David P. Casper ${ }^{1}$ \\ Department of Dairy Science, South Dakota State University, Brookings 57007
}

\begin{abstract}
The study objective was to determine if feeding the rumen-degradable AA Val can increase milk production comparable to recombinant bovine somatotropin (bST). Eight multiparous late-lactating ( $255 \pm 26.4 \mathrm{~d}$ in milk) Holstein dairy cows were blocked by milk yield (34.1 \pm $8.25 \mathrm{~kg} / \mathrm{d}$ ) and randomly assigned to 1 of 4 treatments in a replicated $4 \times 4$ Latin square design with 21 -d periods $(7 \mathrm{~d}$ for dietary adaptation and $14 \mathrm{~d}$ for data collection). Treatments were control (CON), a single injection of recombinant bST (rbST), and Val fed at 40 (V40) and $80 \mathrm{~g} / \mathrm{d}(\mathrm{V} 80)$. Cows were fed a total mixed ration with a distillers dried grains carrier at $113.4 \mathrm{~g} / \mathrm{d}$ containing none or added AA. Dry matter intake (21.3, $22.0,22.8$, and $21.5 \mathrm{~kg} / \mathrm{d}$ for $\mathrm{CON}$, rbST, V40, and V80, respectively) was similar among treatments, except cows receiving V40 had greater dry matter intake than cows receiving V80. Milk yield (22.0, 26.1, 25.2, and $24.9 \mathrm{~kg} / \mathrm{d}), 3.5 \%$ fat-corrected milk (22.1, 25.4, 24.4 , and $24.3 \mathrm{~kg} / \mathrm{d}$ ), and energy-corrected milk (22.7, $26.1,25.1$, and $24.9 \mathrm{~kg} / \mathrm{d}$ ) were increased at similar amounts for cows receiving rbST, V40, and V80 compared with CON cows. Milk fat percentages $(3.51,3.36$, 3.32 , and $3.38 \%$ ) were greatest for CON cows compared with cows receiving V40, whereas cows receiving other treatments were intermediate and similar. Milk protein percentages $(3.20,3.12,3.15$, and $3.13 \%)$ were greater for CON cows compared with cows receiving rbST and V40, whereas cows receiving V80 were intermediate and similar. Ruminal isobutyrate $(1.19,1.24,1.44$, and 1.74 $\mathrm{mol} / 100 \mathrm{~mol}$ ) concentrations were increased for cows receiving V40 and V80 compared with CON and rbST cows, with cows receiving V80 having greater concentrations than cows receiving V40. Plasma growth hormone concentrations $(1.78,1.99,1.55$, and $1.45 \mathrm{ng} / \mathrm{mL})$ were greater for cows receiving rbST compared with
\end{abstract}

Received August 1, 2015.

Accepted October 30, 2015.

${ }^{1}$ Corresponding author: david.casper@sdstate.edu cows receiving V40 and V80, whereas CON cows were intermediate and similar. Plasma insulin-like growth factor- 1 concentrations $(60.4,106.1,65.9$, and $58.3 \mathrm{ng} /$ $\mathrm{mL}$ ) were greater for cows receiving rbST compared with cows receiving other treatments. This study suggests that feeding rumen degradable Val can increase milk yield comparable to recombinant bST.

Key words: amino acid, dairy cow, growth hormone, milk production

\section{INTRODUCTION}

With the world population expected to reach 9 billion people by 2050 (Capper et al., 2008), new approaches and technologies need to be discovered to feed the growing world population. If the world population does indeed reach 9 billion people, milk production will need to increase by more than 22 billion $\mathrm{kg}$ from 2006 production levels (Capper et al., 2008). Achieving this growth will require increased production with very efficient utilization of resources.

It has been difficult and frustrating to achieve consistent milk production responses when balancing rations for metabolizable AA on commercial dairy operations (D. P. Casper, personal communication). Feed formulation software packages that give different rations when balancing for AA due to different methods for calculating requirements is just one of many concerns. One issue with AA balancing is the lack of knowledge on how much AA gets metabolized by the rumen, how much escapes the rumen, and how much is absorbed across the intestinal wall (Kung and Rode, 1996). Some research studies (Zanton et al., 2014) have shown that increasing AA in the diet has led to increased milk production, an important aspect to dairy producers, but other studies (Zanton et al., 2014) have not demonstrated a response. In addition, nutrients and their metabolites can be metabolic regulators. So it may be possible that other mechanism(s) may exist for describing the observed responses of lactating dairy cows when fed rations balanced for AA. Thus, future research needs to identify these new mechanism(s) to create formulation systems that will give accurate and consistent results when 
balancing rations for AA to achieve consistent, predictable, and optimal milk production. The hypothesis of the current study is that the nutrient concentration of the ration may be influencing the endocrine system of the lactating dairy cow.

The dairy industry has made strides in the last few decades to achieve higher milk production through the use of fewer resources. Recombinant bST, which has been shown to increase milk production by 10 to $15 \%$ (Etherton and Bauman, 1998) was approved by the US Food and Drug Administration in 1993 (Capper et al., 2008), and in 1994 recombinant bST became available for commercial use as Posilac (Elanco, Greenfield, IN; Etherton and Bauman, 1998). Although no human health risks have been found in the more than 90,000 research studies conducted on somatotropin (Etherton and Bauman, 1998), the public has not been favorable toward the use of hormones to increase milk production and recombinant bST has been banned in certain countries, including the European Union and Canada (Ozhikandathil et al., 2014), along with certain milk processors and food service companies within the United States, including McDonald's (Dairy Herd Management, 2015) and Starbucks (Organic Consumers Association, 2007).

Isoacids have also been used in the past to enhance milk production of lactating dairy cows via increasing ruminal fiber digestion (Papas et al., 1984; PeirceSandner et al., 1985), but commercialization failed due to an unpleasant odor (National Center for Biotechnology Information, 2015). Liu et al. (2009) demonstrated that feeding isobutyrate (an isoacid) resulted in an $11 \%$ increase in blood growth hormone (GH) concentrations. This observation presents an opportunity to use isobutyrate (Val metabolite) to stimulate the release of natural GH from the anterior pituitary.

One potential alternative to feeding isobutyrate is to feed the synthetic AA, Val, which does not emit any unpleasant odors. Our hypothesis was that Val will be metabolized by the rumen microbes to isobutyric acid through ruminal microbial oxidative deamination and decarboxylation (Rosener and Uhlenhopp, 1987), which will then be absorbed across the rumen wall into the blood stream. Increased blood concentrations of isobutyrate will stimulate additional GH release from the pituitary gland, which will then enhance milk production through the GH-IGF-1 axis. Thus, the objective of our study was to determine if the supplementation of synthetic Val could increase milk production that would be similar to the administration of recombinant bST, and therefore become a viable alternative for recombinant bST for dairy producers that are not allowed to use recombinant bST.

\section{MATERIALS AND METHODS}

\section{Animals and Diets}

This research project was conducted at the South Dakota State University (SDSU) Dairy Research and Training Facility (DRTF; Brookings, SD) from April 22 to July 27, 2014, and all procedures were approved by the SDSU Institutional Animal Care and Use Committee before the start of the study. Eight multiparous late-lactating $(255 \pm 26.4$ DIM) Holstein dairy cows housed in a freestall barn were blocked by milk production $(34.1 \pm 8.25 \mathrm{~kg} / \mathrm{d})$ and randomly assigned to 1 of 4 treatments using a replicated $4 \times 4$ Latin square design having 21 -d periods with $7 \mathrm{~d}$ for dietary adaptation and $14 \mathrm{~d}$ for data collection. Treatments were (1) control (no injection of recombinant bST or Val supplementation; CON), (2) a single injection of 14-d slow-release recombinant bST (Posilac, Elanco) given on d 1 of wk 2 of each period subcutaneously to either the right or left side of the tailhead (rbST), (3) Val (L-Val, Ajinomoto North America Inc., Fort Lee, NJ) fed at $40 \mathrm{~g} / \mathrm{d}$ (V40), and (4) Val fed at $80 \mathrm{~g} / \mathrm{d}(\mathbf{V 8 0})$.

Cows were fed a TMR (Table 1 ) once a day consisting of $55 \%$ forage $(60 \%$ corn silage and $40 \%$ alfalfa haylage from the 2013 crop season) and $45 \%$ grain on a DM basis with a distillers dried grains carrier included at the rate of $113.4 \mathrm{~g} / \mathrm{d}$ that contained none or added Val at the designated amounts. The grain mix was similar among all 4 treatments and was mixed at the SDSU Feed Mill and delivered to the DRTF approximately every $2 \mathrm{wk}$. The ration was balanced using Agricultural Modeling and Training Systems (AMTS) software (Agricultural Modeling and Training Systems LLC, Groton, NY) for $38.5 \mathrm{~kg} / \mathrm{d}$ of milk produced by cow weighing $703 \mathrm{~kg}$ that was assumed to be pregnant (NRC, 2001). The Val content in the TMR before the addition of Val was formulated to provide $121 \%$ of the daily requirement of metabolizable Val for the cow at $139.9 \mathrm{~g} / \mathrm{d}$. This was calculated using the set equations and values in the AMTS software (Agricultural Modeling and Training Systems). All other essential AA were balanced to meet or exceed the requirements of a lactating dairy cow at this stage of production (NRC, 2001). The TMR and distillers dried grains carrier were mixed for 5 min using a Super Data Ranger (American Calan Inc., Northwood, NH) before dispensing the TMR.

Twelve days before the beginning of the study were used for training cows to use the Calan Door System. This study did not use Rumensin (Elanco Animal Health, Indianapolis, IN), and recombinant bST shots were discontinued before the Calan Door System training period and given to the $\operatorname{rbST}$ treatment on $\mathrm{d} 1$ of 
wk 2 of each period. Cows were fed once daily at $0500 \mathrm{~h}$ using the Super Data Ranger to achieve 10\% feed refusals and refusals were collected daily before feeding. A feed sheet for the Super Data Ranger was used to record daily feeding data. Cows had unlimited access to fresh water and were milked 3 times per day at 0700, 1500, and $2300 \mathrm{~h}$. All other bedding, cow monitoring, and manure scraping followed normal DRTF procedures.

\section{Sampling}

Milk production was recorded electronically (DeLaval-ALPRO, Kansas City, MO) at each individual milking and saved daily to a universal serial bus flash drive. Any milk weights that were not recorded properly were calculated by averaging the milk weight from the indi-

Table 1. Ingredient composition of the $\mathrm{TMR}^{1,2}$

\begin{tabular}{|c|c|}
\hline Ingredient & $\%$ of DM \\
\hline Corn silage & 33.0 \\
\hline Alfalfa silage, $178 \mathrm{RFQ}^{3}$ & 22.0 \\
\hline Corn grain, fine ground & 18.0 \\
\hline Soybean hulls, ground & 5.75 \\
\hline Cottonseed, fuzzy & 5.37 \\
\hline Soybean meal, $48 \% \mathrm{CP}$ & 4.50 \\
\hline Dried distillers grains & 4.43 \\
\hline Soy Best PEARL ${ }^{4}$ & 2.23 \\
\hline Corn gluten meal & 0.68 \\
\hline Calcium carbonate & 0.58 \\
\hline Energy Booster $100^{5}$ & 0.50 \\
\hline Sodium bicarbonate & 0.50 \\
\hline Animal fat & 0.42 \\
\hline Salt, white & 0.42 \\
\hline Dicalcium phosphate, $20 \% \mathrm{Ca}, 18.5 \% \mathrm{P}$ & 0.25 \\
\hline Potassium chloride, white & 0.17 \\
\hline Magnesium oxide & 0.17 \\
\hline Trace mineral premix ${ }^{6}$ & 0.17 \\
\hline Urea & 0.17 \\
\hline Diamond $\mathrm{V} \mathrm{XP} \mathrm{XP}^{7}$ & 0.15 \\
\hline Diamond V SelenoSource AF $2000^{7}$ & 0.13 \\
\hline Vitamin premix E, 44,000 IU $/ \mathrm{kg}$ & 0.05 \\
\hline Vitamin premix $\mathrm{ADE}^{8}$ & 0.02 \\
\hline Supplement ${ }^{9}$ & 0.36 \\
\hline
\end{tabular}

${ }^{1}$ The TMR had a forage-to-concentrate ratio of 55:45 (DM basis) with the forage ratio containing $60 \%$ corn silage and $40 \%$ alfalfa haylage.

${ }^{2}$ The TMR ration was formulated using Agricultural Modeling and Training Systems software (Agricultural Modeling and Training Systems, Groton, NY).

${ }^{3} \mathrm{RFQ}=$ relative forage quality.

${ }^{4}$ Kemin, West Point, NE.

${ }^{5}$ Milk Specialties Global, Eden Prairie, MN.

${ }^{6} 3,500 \mathrm{mg} / \mathrm{kg}$ of $\mathrm{Zn}, 2,000 \mathrm{mg} / \mathrm{kg}$ of Fe, $1,800 \mathrm{mg} / \mathrm{kg}$ of Mn, $420 \mathrm{mg} /$ $\mathrm{kg}$ of $\mathrm{Cu}, 100 \mathrm{mg} / \mathrm{kg}$ of I, and $60 \mathrm{mg} / \mathrm{kg}$ of Co.

${ }^{7}$ Diamond V, Cedar Rapids, IA.

${ }^{8} 3,306,000 \mathrm{IU} / \mathrm{kg}$ of vitamin $\mathrm{A}, 1,102,000 \mathrm{IU} / \mathrm{kg}$ of vitamin $\mathrm{D}$, and $1,100 \mathrm{IU} / \mathrm{kg}$ of vitamin E.

${ }^{9}$ Dried distillers grains carrier containing none or added Val at designated amounts for the following treatments: control (no injection of recombinant bST or supplemental Val), single injection of recombinant $\mathrm{bST}, 40 \mathrm{~g} / \mathrm{d}$ of Val, and $80 \mathrm{~g} / \mathrm{d}$ of Val. vidual milking from the day before and the day after the missing datum. Two milk samples were collected on Tuesday and Friday of wk 2 and 3 of each treatment period from each individual milking. One set of milk samples were composited by day on a weighted basis proportional to milk production and frozen for potential future analysis at $-20^{\circ} \mathrm{C}$. The other set of individual milk samples were sent to DHIA Heart of America (Manhattan, KS) for analysis of fat, protein, SCC, lactose, and MUN using AOAC International (2002) approved procedures. Milk fat, protein, and lactose were analyzed using near infrared spectroscopy (Bentley 2000 Infrared Milk Analyzer, Bentley Instruments, Chaska, MN). Milk urea nitrogen concentrations were determined using chemical methodology based on a modified Berthelot reaction (ChemSpec 150 Analyzer, Bentley Instruments). Somatic cell counts were determined using a flow cytometer laser (Somacount 500, Bentley Instruments). Somatic cell counts were converted to a linear SCS using the following equation: $\{[\ln (\mathrm{SCC} / 100)] / 0.693147\}+3$, as described by Schroeder (2012). Fat-corrected milk (3.5\%) was determined using the equation $(0.432 \times \mathrm{kg}$ of milk $)+(16.216 \times \mathrm{kg}$ of fat), and ECM was determined using the equation $(0.327 \times \mathrm{kg}$ of milk $)+(12.95 \times \mathrm{kg}$ of fat $)+(7.65 \times \mathrm{kg}$ of protein) as described by Orth (1992).

Dry matter composition of forages was determined weekly by drying in a $105^{\circ} \mathrm{C}$ oven (Despatch LEBI-75, Despatch Industries, Minneapolis, MN) for $24 \mathrm{~h}$ and feed sheets adjusted accordingly. Samples of the grain mix, individual forages, and TMR were collected once during wk 2 and 3 of each period for nutrient analyses and stored at $-20^{\circ} \mathrm{C}$.

Rumen fluid samples were collected on Tuesday of wk 2 and 3 and Friday of wk 3 of each period at $3 \mathrm{~h}$ after feeding, and Friday of wk 2 of each period every $3 \mathrm{~h}$ from 0 to $9 \mathrm{~h}$ after feeding via esophageal tube, which was coated with lubricant (Wal-Mart Stores, Inc., Bentonville, AR) to reduce risk of irritation of the esophagus and attached to a hand-operated pump. The first $100 \mathrm{~mL}$ of rumen fluid was discarded to minimize saliva contamination. After collection, rumen fluid was mixed thoroughly and $\mathrm{pH}$ was measured immediately using an electronic $\mathrm{pH}$ meter (Corning 350, Corning Inc., Corning, NY). If the rumen fluid collected was at a $\mathrm{pH}>7.0$, rumen fluid was discarded and additional rumen fluid was collected to ensure minimal saliva contamination. Two 10-mL samples of rumen fluid were collected, where one 10-mL sample was added to a vial containing $200 \mu \mathrm{L}$ of $50 \%$ ( vol/vol) $\mathrm{H}_{2} \mathrm{SO}_{4}$ for later determination of $\mathrm{NH}_{3}-\mathrm{N}$ and the other $10-\mathrm{mL}$ sample was added to a vial containing $2 \mathrm{~mL}$ of $25 \%$ (wt/vol) meta-phosphoric acid for later determination of VFA. 
After sample collection and preparation, rumen fluid samples were immediately stored at $-20^{\circ} \mathrm{C}$.

Two 10-mL coccygeal artery and two 10-mL mammary vein blood samples were collected using Vacutainer tubes containing $\mathrm{K}_{2}$-EDTA (Becton Dickinson Vacutainer Systems, Rutherford, NJ) on Tuesday and Friday of wk 2 and 3 of each period $3 \mathrm{~h}$ after feeding for later analysis of nonesterified fatty acids (NEFA) and VFA concentrations. One 6-mL coccygeal artery blood sample using a Vacutainer tube containing sodium fluoride (Becton Dickinson Vacutainer Systems) was also collected on Tuesday and Friday of wk 2 and 3 of each period $3 \mathrm{~h}$ after feeding for later analysis of glucose.

All cows were moved to the veterinary wing of the DRTF on Thursday of wk 2 of each period, where they were housed in individual stalls and could be restrained in headlocks. At this time, jugular catheters were inserted under veterinary supervision (Michele Mucciante, SDSU Veterinarian, Brookings). Prior to catheter insertion, cows were restrained in the headlocks with their head tied to one side using a rope halter to allow easy access to the insertion site. The insertion site was then clipped using an electric clipper with a 40-tooth comb (model PCMC-2, Wahl Clipper Corporation, Sterling, IL). Next, the insertion site was scrubbed with betadine solution (Purdue Pharmaceuticals L.P., Yonkers, NY) and betadine scrub (Purdue Pharmaceuticals L.P.) 3 times before being cleaned with $70 \%$ isopropyl rubbing alcohol (Vi-Jon, Saint Louis, MO). After the insertion site was properly cleaned, a small incision was made in the hide over the catheter insertion site approximately 1 to $2 \mathrm{~cm}$ in length using a \#12 hook blade scalpel (HMD Healthcare USA Inc., Cary, NC). A 14 gauge $\times 14.0 \mathrm{~cm}$ indwelling IV catheter (Hospira Inc., Lake Forest, IL) was then inserted into the jugular vein approximately 2.5 to $3.5 \mathrm{~cm}$ deep, with the bevel of the needle against the animal's hide and the needle tip down. When inserted properly, blood flow would result and the catheter was slid off of the needle into the cow's jugular vein so that the needle could be removed. If blood flow did not result after initial insertion, the catheter was repositioned by moving in or out without removing the catheter from the hide. Once the catheter was in the jugular vein and the needle removed, a 53-cm catheter extension tube (Baxter Healthcare Corporation, Deerfield, IL) was attached to the catheter to allow for easy blood sampling without disturbing the insertion site and flushed with $10 \mathrm{~mL}$ of saline (Nova-Tech Inc., Grand Island, NE) and 5 $\mathrm{mL}$ of $\mathrm{Na}$ heparin solution [Na heparin (Sagent Pharmaceuticals Inc., Schaumburg, IL) mixed with saline to make a concentration of $200 \mathrm{U} / \mathrm{mL}$ ] using a $20-\mathrm{mL}$ syringe before capping the extension tube with a Surflo Injection Plug (Terumo Medical Corporation, Somer- set, NJ). Next, the end of the catheter was superglued to the cow's hide and a $10.2 \times 10.2 \mathrm{~cm}$ piece of Vetwrap (3M, Maplewood, MN) was glued with Livestock Identification Tag Cement (W. J. Ruscoe Company, Akron, $\mathrm{OH}$ ) around the catheter and extension. Then 1 roll of 7.6-cm Elastikon tape (Johnson and Johnson Consumer Companies Inc., Skillman, NJ) was wrapped around the cow's neck over the catheter insertion site and approximately one third of the extension tube so that no direct force would be applied to the catheter when working with the extension tube. After that, 1 roll of 10.2-cm Vetwrap was wrapped around the cow's neck to contain the remainder of the extension tube. Finally, a human rib belt (Alpha Medical Instruments LLC, Rock Hill, SC) was placed around the cow's neck to provide extra protection of the catheter.

On the morning of sampling, approximately $1 \mathrm{~h}$ before sampling began, a 5 -mL sample of blood was drawn through the catheters using a $20-\mathrm{mL}$ syringe and discarded to check for patency and then flushed with 10 $\mathrm{mL}$ of saline and $5 \mathrm{~mL}$ of $\mathrm{Na}$ citrate solution [ $\mathrm{Na}$ citrate (Fenwal Inc., Lake Zurich, IL) mixed with saline to make a concentration of $10 \mathrm{mg} / \mathrm{mL}$ ]. If it was determined that a catheter needed to be replaced, the old catheter was removed and a new catheter was inserted into the opposite jugular vein. Cows were carefully monitored for infection or irritation around the catheter insertion site, if any adverse reactions occurred the catheter was replaced. Once sampling began, 2 jugular vein blood samples were collected using 7.5-mL S-Monovette tubes containing $\mathrm{K}_{2}$-EDTA (Sarstedt Ag and Company, Nümbrecht, Germany) and a multi-adapter (Sarstedt $\mathrm{Ag}$ and Company), which connected the S-Monovette tubes to the catheter extension tube, on Friday of wk 2 of each period via indwelling catheter every hour from 0 to $9 \mathrm{~h}$ after feeding for later analysis of GH and IGF-1. An initial $5 \mathrm{~mL}$ of blood was withdrawn and discarded before collecting the sample to avoid contamination with the Na citrate solution used to flush the catheter. After sampling began, $10 \mathrm{~mL}$ of saline and $5 \mathrm{~mL}$ of $\mathrm{Na}$ citrate solution were flushed through the catheter after each sample was taken. Sodium heparin solution was used to flush the catheter overnight because it is a more potent anticoagulant, but when sampling at intervals of less than $1 \mathrm{~h}, \mathrm{Na}$ citrate was used to prevent heparin-induced activation of lipoprotein lipase and subsequent elevation of blood NEFA concentrations (Anderson, 1982). All blood samples were collected and immediately stored on ice until transported to the laboratory and centrifuged at 2,000 $\times g$ for $20 \mathrm{~min}$ at $8^{\circ} \mathrm{C}$ (CR412 centrifuge; Jouan Inc., Winchester, VA) to separate plasma. After separation, plasma was stored in 5 -mL tubes at $-20^{\circ} \mathrm{C}$. Once sampling was completed, jugular catheters were removed and a $5 \times 5 \mathrm{~cm}$ gauze 
pad (Medline Industries Inc., Mundelein, IL) was held to the injection site until bleeding stopped. Then the injection site was coated with Povidine First Aid Ointment (Major Pharmaceuticals, Livonia, MI).

Body condition scores were determined weekly during wk 2 and 3 of each period by 3 individuals on a scale of 1 to 5 , with 1 as emaciated and 5 as obese (Wildman et al., 1982), approximately $3 \mathrm{~h}$ after feeding. Body condition score changes by week were calculated for each cow by subtracting BCS of wk 2 from wk 3 . Body weights were electronically collected using a livestock scale (model AWB-5K-SYS, Triner Scale and Manufacturing Company Inc., Olive Branch, MS) on Tuesday of wk 2 and 3, Thursday of wk 2, and Friday of wk 3 of each period, approximately $3 \mathrm{~h}$ after feeding. Body weight changes by day were calculated for each cow by subtracting weights from Tuesday of wk 2 from Friday of wk 3 and dividing by $10 \mathrm{~d}$.

\section{Laboratory Analysis}

At the end of the trial, feed samples were thawed and composited by period before being sent to Analab (Fulton, IL) for DM and nutrient analysis (Table 1). Samples were analyzed using the following AOAC International (1998) methods: DM (935.29), CP (990.03), NDF (2002.04), ADF (973.18), ADIN (973.18 and 976.06), neutral detergent insoluble protein (2002.04, without sulfite, and 976.06), lignin (973.18), ash (942.05), Ca (985.01), P (985.01), Mg (985.01), Na (985.01), $\mathrm{Cl}$ (915.01), S (923.01), $\mathrm{Fe}$ (985.01), $\mathrm{Cu}$ (985.01), Zn (985.01), K (985.01), Mn (985.01), and $\mathrm{pH}$ (981.12). The remaining nutrient parameters were measured using the following methods: soluble protein (Krishnamoorthy et al., 1982), starch (Glucose Reagent Set, Amresco, Solon, OH; Alpkem Corporation, 1990), oil (Damon, 1966), in vitro DM digestibility [24-h ruminal and 24-h enzymatic digestion using the Kansas State Buffer (Marten and Barnes, 1980)], NDF digestibility [Van Soest et al., 1991; incubated for 30 h using the Kansas State Buffer (Marten and Barnes, 1980)], $\mathrm{NH}_{3}-\mathrm{N}$ (US EPA, 1993, method 351.2; ISO, 2013, method 11732), lactic acid (El Rassi, 1996), acetic acid (Cancalon, 1993), NFC (NRC, 2001), $\mathrm{NE}_{\mathrm{L}}$ (NRC, 2001), relative forage quality (Rohweder et al., 1978), and sugar (Analab-defined method, in process of entering a single laboratory validation from the Association of American Feed Control Officials, Champaign, IL).

Rumen fluid samples were thawed and centrifuged at $30,000 \times g$ for $20 \mathrm{~min}$ at $20^{\circ} \mathrm{C}$ (Eppendorf 5403, Eppendorf North America, Hauppauge, NY). Rumen fluid samples acidified with $50 \%$ ( $\mathrm{vol} / \mathrm{vol}$ ) $\mathrm{H}_{2} \mathrm{SO}_{4}$ were analyzed for $\mathrm{NH}_{3}-\mathrm{N}$ using procedures from Chaney and Marbach (1962). Ruminal fluid samples acidified with $25 \%$ (wt/vol) meta-phosphoric acid were prepared according to Erwin et al. (1961) and analyzed for VFA concentrations using an automated gas-liquid chromatograph (model 6890, Hewlett-Packard) with a flame-ionization detector. Once prepared, $1 \mu \mathrm{L}$ of prepared sample was injected at a split ratio of 30:1 at the injection port $\left(250^{\circ} \mathrm{C}\right)$. Volatile fatty acids were separated on a capillary column $(15 \mathrm{~m} \times 0.25 \mathrm{~mm}$ i.d.; Nukol, 17926-01C, Supelco Inc., Bellefonte, PA) with flow-rate of $30 \mathrm{~mL} / \mathrm{min}$ of He using 2-ethylbutyrate as an internal standard. The column and detector temperature were maintained at 140 and $250^{\circ} \mathrm{C}$, respectively.

Blood plasma taken $3 \mathrm{~h}$ after feeding was analyzed for glucose [Liquid Glucose (Oxidase) Reagent Set; Pointe Scientific Inc., Canton, MI], NEFA [HR Series NEFA-HR(2) Microtiter Procedure, Wako Diagnostics, Richmond, VA], and VFA. Plasma VFA concentrations were analyzed by GC (model 6890, Hewlett-Packard, Avondale, PA). Samples were prepared according to Oba and Allen (2003). Once prepared, $1 \mu \mathrm{L}$ of prepared sample was injected at a split ratio of 2:1 at the injection port $\left(280^{\circ} \mathrm{C}\right)$. Volatile fatty acids were separated on a capillary column $(15 \mathrm{~m} \times 0.25 \mathrm{~mm}$ i.d.; Nukol, 17926-01C, Supelco Inc.) with a flow of $45 \mathrm{~mL} / \mathrm{min}$ of He using 2-ethylbutyrate as an internal standard. Initial oven temperature was $100^{\circ} \mathrm{C}$ for 6 min and then was increased by $5^{\circ} \mathrm{C} / \mathrm{min}$ to $120^{\circ} \mathrm{C}$, where it was held for $5 \mathrm{~min}$. The oven was brought up to $170^{\circ} \mathrm{C}$ for purging at the end of the run. The flame ionization detector was maintained at $300^{\circ} \mathrm{C}$.

Plasma concentrations of GH and IGF-1 were determined for samples collected 0 to $9 \mathrm{~h}$ after feeding on Friday of wk 2 of each period. Plasma concentrations of GH were determined in duplicate by RIA using procedures as described by Klindt et al. (1983). Bovine GH (AFP-9884C, National Hormone and Peptide Program, National Institutes of Diabetes, Digestive and Kidney Diseases, Bethesda, MD) was used as the radioiodinated antigen and standard. Growth hormone antiserum (AFPB55, National Hormone and Peptide Program) was used at an initial dilution of 1:200,000. Plasma concentrations of IGF-1 were determined in duplicate by RIA (Echternkamp et al., 1990; Funston et al., 1995). Insulin-like growth factor binding proteins were extracted from plasma using a 1:17 ratio of sample to acidified ethanol (12.5\% $2 \mathrm{~N} \mathrm{HCl:} 87.5 \%$ absolute ethanol; Daughaday et al., 1980). Extracted samples were centrifuged $\left(12,000 \times g\right.$ at $4^{\circ} \mathrm{C}$ for $\left.10 \mathrm{~min}\right)$ to separate IGF binding protein. A portion of the resulting supernatant was removed and neutralized with $0.855 M$ Tris base, incubated for an additional $4 \mathrm{~h}$ at $4^{\circ} \mathrm{C}$, and then centrifuged at $12,000 \times g$ at $4^{\circ} \mathrm{C}$ for $10 \mathrm{~min}$ to remove any additional IGF binding protein. Recombinant human IGF-1 (GF-050; Austral Biological, San Ramon, 
CA) was used as the standard and radioiodinated antigen. Antisera AFP 4892898 (National Hormone and Peptide Program) was used at a dilution of 1:62,500.

\section{Statistical Analysis}

All data were subjected to least squares ANOVA for a replicated $4 \times 4$ Latin square design using the PROC MIXED procedure of SAS (version 9.3, SAS Institute Inc., Cary, NC) as a repeated measures ANOVA. Milk production, 3.5\% FCM, ECM, milk fat yield, milk protein yield, feed efficiency $(\mathbf{F E})$, and DMI were averaged by week during wk 2 and 3 . Means for the remaining variables were calculated from the data gathered during the collection time for each period. The statistical model used was

$$
\begin{gathered}
\mathrm{Y}_{\mathrm{ijkl}}=\mu+\mathrm{T}_{\mathrm{i}}+\mathrm{P}_{\mathrm{j}}+\mathrm{C}\left(\mathrm{S}_{1}\right)+\mathrm{S}_{1}+(\mathrm{T} \times \mathrm{S}) \\
+\mathrm{TM}_{\mathrm{k}}+(\mathrm{T} \times \mathrm{TM}),
\end{gathered}
$$

where $Y_{\mathrm{ijlk}}=$ dependent variable, $\mu=$ overall mean, $\mathrm{T}_{\mathrm{i}}$ $=$ treatment, $\mathrm{P}_{\mathrm{j}}=$ period, $\mathrm{C}\left(\mathrm{S}_{1}\right)=$ cow within square, $\mathrm{S}_{1}=$ square, $(\mathrm{T} \times \mathrm{S})=$ treatment by square, $\mathrm{TM}_{\mathrm{k}}=$ time, and $(\mathrm{T} \times \mathrm{TM})=$ treatment by time, where time $=$ week for milk production, 3.5\% FCM, ECM, milk fat yield, milk protein yield, FE, DMI, BCS, and BCS change; time = day for milk fat $(\%)$, milk protein $(\%)$, lactose, MUN, SNF, SCS, BW, BW change, $\mathrm{pH}, \mathrm{NH}_{3}-$ $\mathrm{N}, \mathrm{VFA}$, glucose, and NEFA; and time = hour for $\mathrm{GH}$, IGF-1, $\mathrm{pH}, \mathrm{NH}_{3}-\mathrm{N}$, and VFA. Time was considered a repeated measurement having an autoregressive covariance structure. If the probability of the interaction of $\mathrm{T} \times \mathrm{S}$ was greater than 0.1 , this interaction was eliminated from the model. Significant differences were declared when $P<0.05$ and trends declared at $0.05 \leq$ $P<0.10$.

\section{RESULTS}

\section{Feed Analysis}

The TMR analysis for this study resulted in a similar nutrient composition as the original diet that was balanced using AMTS software (Agricultural Modeling and Training Systems). The diet was $17.2 \%$ CP, 1.72 $\mathrm{Mcal} / \mathrm{kg}$ of $\mathrm{NE}_{\mathrm{L}}, 32.1 \% \mathrm{NDF}, 20.6 \% \mathrm{ADF}$, and $41.5 \%$ NFC on a DM basis (Table 2). The TMR met or exceeded recommended nutrient guidelines (NRC, 2001).

\section{Milk Production, Composition, and Quality}

Milk production, $3.5 \% \mathrm{FCM}$, and ECM were all greater $(P<0.05)$ for cows receiving rbST, V40, and
V80 compared with CON cows, but the increased milk yield was similar $(P \geq 0.10)$ among cows receiving rbST, V40, and V80 (Table 3). The increase in milk yield averaged $3.4 \mathrm{~kg} / \mathrm{d}$ for cows receiving rbST, V40, and V80 compared with CON cows, with a range from 2.9 to 4.1 $\mathrm{kg} / \mathrm{d}$. Milk fat percentages were decreased $(P<0.05)$ for cows receiving V40 compared with CON cows, with cows receiving rbST and V80 being intermediate and similar $(P \geq 0.10)$. Although milk fat percentages were decreased for cows receiving V40, milk fat yields for cows receiving rbST and V40 were greater $(P<0.05)$ than CON cows, with cows receiving V80 being intermediate and similar $(P \geq 0.10)$. Milk protein percentages were decreased $(P<0.05)$ for cows receiving rbST and V40 compared with CON cows and cows receiving

Table 2. Nutrient composition (\% of DM unless otherwise noted) of

\begin{tabular}{|c|c|c|c|c|}
\hline \multirow[b]{2}{*}{ Nutrient } & \multicolumn{4}{|c|}{ Feed ingredient ${ }^{1}$} \\
\hline & GM & CS & $\mathrm{AH}$ & $\mathrm{TMR}^{2,3}$ \\
\hline $\mathrm{DM}, \%$ & 86.5 & 34.5 & 55.9 & 53.7 \\
\hline $\mathrm{CP}$ & 20.3 & 7.98 & 23.7 & 17.2 \\
\hline $\mathrm{SP}^{4} \% \mathrm{CP}$ & 27.2 & 58.1 & 53.2 & 42.2 \\
\hline $\mathrm{NDF}$ & 23.7 & 40.2 & 37.2 & 32.1 \\
\hline $\mathrm{ADF}$ & 14.6 & 23.8 & 27.6 & 20.6 \\
\hline ADIN & - & 0.25 & 1.25 & 0.68 \\
\hline NDIP $^{5}$ & 3.19 & 0.55 & 0.55 & 1.54 \\
\hline NFC & 45.2 & 45.2 & 32.2 & 41.5 \\
\hline Sugar & - & 0.21 & 6.52 & 2.04 \\
\hline Starch & 28.5 & 33.9 & - & 23.6 \\
\hline $\mathrm{NE}_{\mathrm{L}}, \mathrm{Mcal} / \mathrm{kg}$ & $\ldots$ & 1.65 & 1.57 & 1.72 \\
\hline Oil & 7.00 & 2.92 & 1.80 & 4.24 \\
\hline IVDMD $^{6}$ & - & 71.8 & 74.2 & 80.8 \\
\hline $\mathrm{NDFD}^{7} \% \mathrm{NDF}$ & - & 46.6 & 55.2 & 58.0 \\
\hline Lignin & - & 2.04 & 6.38 & 3.62 \\
\hline Ash & 6.96 & 4.25 & 8.16 & 6.52 \\
\hline $\mathrm{NH}_{3}-\mathrm{N}, \mathrm{mg} / \mathrm{kg}$ & - & 1,217 & 2,630 & - \\
\hline $\mathrm{Ca}$ & 0.79 & 0.25 & 1.50 & 0.76 \\
\hline $\mathrm{P}$ & 0.51 & 0.23 & 0.33 & 0.37 \\
\hline $\mathrm{Mg}$ & 0.41 & 0.21 & 0.42 & 0.34 \\
\hline $\mathrm{K}$ & 1.17 & 0.76 & 2.14 & 1.35 \\
\hline $\mathrm{Na}$ & 0.63 & 0.06 & 0.13 & 0.34 \\
\hline $\mathrm{Cl}$ & 0.72 & 0.15 & 0.42 & 0.57 \\
\hline $\mathrm{S}$ & 0.25 & 0.06 & 0.32 & 0.22 \\
\hline $\mathrm{Fe}, \mathrm{mg} / \mathrm{kg}$ & 279 & 176 & 290 & 327 \\
\hline $\mathrm{Cu}, \mathrm{mg} / \mathrm{kg}$ & 32.5 & 5.00 & 9.25 & 23.4 \\
\hline $\mathrm{Zn}, \mathrm{mg} / \mathrm{kg}$ & 177 & 57.8 & 37.8 & 116 \\
\hline $\mathrm{Mn}, \mathrm{mg} / \mathrm{kg}$ & 148 & 43.5 & 54.0 & 108 \\
\hline $\mathrm{pH}, 0-14$ & - & 3.88 & 5.05 & - \\
\hline Lactic acid & - & 4.52 & 3.54 & - \\
\hline Acetic acid & - & 3.54 & 0.19 & - \\
\hline
\end{tabular}
grain mix (GM), corn silage (CS), alfalfa haylage (AH), and TMR

${ }^{1}$ The TMR had a forage-to-concentrate ratio of 55:45 (DM basis) with the forage ratio containing $60 \% \mathrm{CS}$ and $40 \% \mathrm{AH}$.

${ }^{2}$ The nutrient composition of the TMR was an average of the TMR for each treatment.

${ }^{3}$ The base diet provided $139.9 \mathrm{~g} / \mathrm{d}$ of metabolizable valine to the cow. ${ }^{4} \mathrm{SP}=$ soluble protein.

${ }^{5} \mathrm{NDIP}=$ neutral detergent-insoluble protein.

${ }^{6}$ IVDMD $=$ in vitro dry matter digestibility.

${ }^{7} \mathrm{NDFD}=$ neutral detergent fiber digestibility, $30 \mathrm{~h}$. 
Table 3. Milk production, composition, and quality of late-lactating dairy cows

\begin{tabular}{lccccc}
\hline & \multicolumn{5}{c}{ Treatment $^{1}$} \\
\cline { 2 - 5 } Measurement & CON & rbST & V40 & V80 & SEM \\
\hline Milk, kg/d & $22.0^{\mathrm{b}}$ & $26.1^{\mathrm{a}}$ & $25.2^{\mathrm{a}}$ & $24.9^{\mathrm{a}}$ & 2.06 \\
$3.5 \% \mathrm{FCM}{ }^{2} \mathrm{~kg} / \mathrm{d}$ & $22.1^{\mathrm{b}}$ & $25.4^{\mathrm{a}}$ & $24.4^{\mathrm{a}}$ & $24.3^{\mathrm{a}}$ & 2.08 \\
$\mathrm{ECM},{ }^{3} \mathrm{~kg} / \mathrm{d}$ & $22.7^{\mathrm{b}}$ & $26.1^{\mathrm{a}}$ & $25.1^{\mathrm{a}}$ & $24.9^{\mathrm{a}}$ & 2.09 \\
Fat, $\%$ & $3.51^{\mathrm{a}}$ & $3.36^{\mathrm{ab}}$ & $3.32^{\mathrm{b}}$ & $3.38^{\mathrm{ab}}$ & 0.13 \\
Fat, kg/d & $0.78^{\mathrm{c}}$ & $0.87^{\mathrm{a}}$ & $0.84^{\mathrm{b}}$ & $0.83^{\mathrm{abc}}$ & 0.08 \\
Protein, \% & $3.20^{\mathrm{a}}$ & $3.12^{\mathrm{b}}$ & $3.15^{\mathrm{b}}$ & $3.13^{\mathrm{ab}}$ & 0.08 \\
Protein, $\mathrm{kg} / \mathrm{d}$ & $0.71^{\mathrm{b}}$ & $0.82^{\mathrm{a}}$ & $0.80^{\mathrm{a}}$ & $0.78^{\mathrm{a}}$ & 0.06 \\
Lactose, \% & 4.58 & 4.57 & 4.61 & 4.60 & 0.13 \\
SNF, \% & $8.67^{\mathrm{a}}$ & $8.57^{\mathrm{b}}$ & $8.65^{\mathrm{ab}}$ & $8.62^{\mathrm{ab}}$ & 0.21 \\
MUN, mg/dL & $11.3^{\mathrm{bc}}$ & $10.9^{\mathrm{c}}$ & $12.3^{\mathrm{a}}$ & $12.3^{\mathrm{ab}}$ & 0.49 \\
SCS & 4.61 & 4.69 & 4.66 & 4.61 & 0.56 \\
\hline
\end{tabular}

${ }^{\mathrm{a}-\mathrm{c}}$ Means within a row with different superscripts differ $(P<0.05)$.

${ }^{1} \mathrm{CON}=$ control (no injection of recombinant bST or supplemental Val); rbST $=$ single injection of recombinant $\mathrm{bST} ; \mathrm{V} 40=40 \mathrm{~g} / \mathrm{d}$ of Val; V80 = $80 \mathrm{~g} / \mathrm{d}$ of Val.

${ }^{2} 3.5 \%$ FCM was determined using the following equation: $(0.432 \times \mathrm{kg}$ of milk $)+(16.216 \times \mathrm{kg}$ of fat $)$ as described by Orth (1992).

${ }^{3} \mathrm{ECM}$ was determined using the following equation: $(0.327 \times \mathrm{kg}$ of milk $)+(12.95 \times \mathrm{kg}$ of fat $)+(7.65 \times \mathrm{kg}$ of protein) as described by Orth (1992).

V80 were intermediate and similar $(P \geq 0.10)$, but milk protein yields for cows receiving rbST, V40, and V80 were greater $(P<0.05)$ than CON cows. Solids-not-fat concentrations were increased $(P<0.05)$ for $\mathrm{CON}$ cows compared with cows receiving $\mathrm{rbST}$, with cows receiving V40 and V80 being intermediate and similar $(P \geq$ $0.10)$. Milk urea nitrogen concentrations were greater $(P<0.05)$ for cows receiving V40 and V80 compared with cows receiving rbST, with cows receiving V40 having significantly greater $(P<0.05)$ concentrations and cows receiving V80 tending to have greater $(0.05 \leq P<$ $0.10)$ concentrations than CON cows. Lactose (\%) and SCS were not affected $(P \geq 0.10)$ by treatment.

\section{$D M I$ and FE}

Dry matter intake was significantly decreased $(P$ $<0.05)$ for cows receiving V80 when compared with cows receiving $\mathrm{V} 40$, with $\mathrm{CON}$ and $\mathrm{rbST}$ cows being intermediate and similar $(P \geq 0.10$; Table 4$)$. Feed efficiency, calculated by dividing milk production by DMI, was increased $(P<0.05)$ for cows receiving rbST compared with V40 and CON cows, with cows receiving V80 being intermediate and similar $(P \geq 0.10)$ between rbST- and V40-treated cows. Feed efficiency, calculated by dividing $3.5 \%$ FCM by DMI or by dividing ECM by DMI, was increased $(P<0.05)$ for cows receiving rbST and V80 compared with CON cows, whereas cows receiving V40 were intermediate and similar $(P \geq 0.10)$ between cows receiving V80 and CON cows.

\section{$B W$ and BCS}

Body weights were greater $(P<0.05)$ for cows receiving rbST and V40 compared with CON cows, with cows receiving V80 being intermediate and similar $(P$ $\geq 0.10$ ) between cows CON and V40; however, BW changes were similar $(P \geq 0.10)$ among all treatments (Table 4). Body condition score and BCS changes were similar $(P \geq 0.10)$ among all treatments, except cows receiving V40 tended $(0.05 \leq P<0.10)$ to have increased BCS changes compared with CON cows.

\section{Rumen Fluid Analysis}

Rumen fluid isobutyrate concentrations were greater $(P<0.05)$ for cows receiving V40 and V80 compared with CON and rbST cows, with cows receiving V80 being greater $(P<0.05)$ than cows receiving V40 (Table 5); in general, isobutyrate concentrations peaked around 3 $\mathrm{h}$ after feeding (Figure 1), as would be expected. When measured on an hourly basis, isobutyrate concentrations were greater $(P<0.05)$ in cows receiving V40 and V80 at 3, 6 , and $9 \mathrm{~h}$ after feeding compared with cows receiving other treatments (Table 6). Prior to feeding $(0 \mathrm{~h})$, cows receiving V40 and V80 had greater $(P<$ $0.05)$ isobutyrate concentrations than rbST-treated cows and tended $(0.05 \leq P<0.10)$ to have greater isobutyrate concentrations than CON cows. Valerate concentrations increased $(P<0.05)$ when measured every $3 \mathrm{~h}$ from 0 to $9 \mathrm{~h}$ after feeding for cows receiving V40 compared with CON cows, with cows receiving V40 tending $(0.05 \leq P<0.10)$ to have increased valerate concentrations compared with cows receiving rbST; cows receiving V80 were intermediate and similar $(P \geq$ 0.10 ; Table 6 ). All other rumen fluid VFA concentrations were similar $(P \geq 0.10)$ among treatments. Total VFA concentrations were unaffected and all treatments were similar $(P \geq 0.10)$ in total VFA concentrations. 
Table 4. Dry matter intake, feed efficiency (FE), BW, and BCS of late-lactating dairy cows

\begin{tabular}{|c|c|c|c|c|c|}
\hline \multirow[b]{2}{*}{ Measurement } & \multicolumn{4}{|c|}{ Treatment $^{1}$} & \multirow[b]{2}{*}{ SEM } \\
\hline & $\mathrm{CON}$ & $\operatorname{rbST}$ & V40 & V80 & \\
\hline \multicolumn{6}{|l|}{ DMI } \\
\hline $\mathrm{kg} / \mathrm{d}$ & $21.3^{\mathrm{ab}}$ & $22.0^{\mathrm{ab}}$ & $22.8^{\mathrm{a}}$ & $21.5^{\mathrm{b}}$ & 0.62 \\
\hline$\% \mathrm{BW}$ & $2.77^{\mathrm{ab}}$ & $2.79^{\mathrm{ab}}$ & $2.90^{\mathrm{a}}$ & $2.77^{\mathrm{b}}$ & 0.06 \\
\hline FE, milk/DMI & $1.03^{\mathrm{c}}$ & $1.17^{\mathrm{a}}$ & $1.09^{\mathrm{bc}}$ & $1.15^{\mathrm{ab}}$ & 0.07 \\
\hline $\mathrm{FE}, 3.5 \% \mathrm{FCM} / \mathrm{DMI}$ & $1.03^{\mathrm{b}}$ & $1.15^{\mathrm{a}}$ & $1.06^{\mathrm{ab}}$ & $1.12^{\mathrm{a}}$ & 0.07 \\
\hline $\mathrm{FE}, \mathrm{ECM} / \mathrm{DMI}$ & $1.05^{\mathrm{b}}$ & $1.18^{\mathrm{a}}$ & $1.09^{\mathrm{ab}}$ & $1.15^{\mathrm{a}}$ & 0.07 \\
\hline \multicolumn{6}{|l|}{ BW } \\
\hline Mean, kg & $790^{\mathrm{b}}$ & $806^{\mathrm{a}}$ & $800^{\mathrm{a}}$ & $797^{\mathrm{ab}}$ & 28.8 \\
\hline Change, $\mathrm{kg} / \mathrm{d}$ & 0.44 & 2.21 & 1.45 & 1.55 & 0.60 \\
\hline \multicolumn{6}{|l|}{ BCS, $1-5$} \\
\hline Mean, U & 3.44 & 3.47 & 3.46 & 3.44 & 0.13 \\
\hline Change, U/wk & 0.02 & 0.04 & 0.11 & 0.13 & 0.04 \\
\hline
\end{tabular}

${ }^{\mathrm{a}-\mathrm{c}}$ Means within a row with different superscripts differ $(P<0.05)$.

${ }^{1} \mathrm{CON}=$ control (no injection of recombinant bST or supplemental Val); rbST $=$ single injection of recombinant $\mathrm{bST} ; \mathrm{V} 40=40 \mathrm{~g} / \mathrm{d}$ of Val; V80 $=80 \mathrm{~g} / \mathrm{d}$ of Val.

Ruminal $\mathrm{pH}$ was similar $(P \geq 0.10)$ among treatments and decreased from 0 to $9 \mathrm{~h}$ after feeding, as would be expected. Concentrations of $\mathrm{NH}_{3}-\mathrm{N}$ were similar $(P \geq$ $0.10)$ among all treatments and peaked around $3 \mathrm{~h}$ after feeding.

\section{Blood Analysis}

Blood plasma acetate concentrations were increased $(P<0.05)$ for cows receiving V80 compared with CON and V40 cows, with rbST-treated cows being intermediate and similar $(P \geq 0.10$; Table 7$)$. Propionate concentrations increased $(P<0.05)$ for CON cows compared with cows receiving V80, whereas cows receiving V40 tended $(0.05 \leq P<0.10)$ to have increased concentrations compared with cows receiving V80; cows receiving $\operatorname{rbST}$ were intermediate and similar $(P \geq 0.10)$. Although acetate and propionate concentrations varied among treatments, the acetate-to-propionate ratio remained similar $(P \geq 0.10)$ among treatments. Butyrate concentrations were increased $(P<0.05)$ for cows receiving V40 compared with cows receiving V80 whereas CON cows tended $(0.05 \leq P<0.10)$ to have increased concentrations compared with cows receiving V80, with cows receiving rbST being intermediate and similar $(P$ $\geq 0.10$ ). Isobutyrate and isovalerate concentrations were similar $(P \geq 0.10)$ among all treatments, except cows receiving rbST tended $(0.05 \leq P<0.10)$ to have increased isovalerate concentrations compared with cows receiving V80. Total VFA concentrations increased $(P$ $<0.05$ ) for cows receiving V40 and V80 compared with cows receiving rbST, with CON cows being intermediate and similar $(P \geq 0.10)$. Glucose concentrations did not differ among treatments, but NEFA concentrations increased $(P<0.05)$ for cows receiving rbST compared with CON and V80 cows; likewise, cows receiving rbST

Table 5. Rumen fluid concentrations of VFA, $\mathrm{pH}$, and ammonia- $\mathrm{N}$ collected $3 \mathrm{~h}$ after feeding from latelactating dairy cows

\begin{tabular}{|c|c|c|c|c|c|}
\hline \multirow[b]{2}{*}{ Measurement } & \multicolumn{4}{|c|}{ Treatment $^{1}$} & \multirow[b]{2}{*}{ SEM } \\
\hline & $\mathrm{CON}$ & rbST & V40 & V80 & \\
\hline $\mathrm{pH}$ & 6.25 & 6.23 & 6.22 & 6.31 & 0.09 \\
\hline Total VFA, $\mathrm{m} M$ & 85.4 & 84.9 & 87.8 & 84.6 & 5.77 \\
\hline Acetate (A) & 60.9 & 61.2 & 61.0 & 60.9 & 1.08 \\
\hline Propionate $(\mathrm{P})$ & 22.5 & 22.3 & 21.9 & 21.9 & 1.13 \\
\hline Isobutyrate & $1.19^{\mathrm{c}}$ & $1.24^{\mathrm{c}}$ & $1.44^{\mathrm{b}}$ & $1.74^{\mathrm{a}}$ & 0.04 \\
\hline Butyrate & 10.4 & 10.2 & 10.3 & 10.3 & 0.22 \\
\hline Isovalerate & 2.80 & 2.76 & 2.87 & 2.78 & 0.17 \\
\hline Valerate & 2.32 & 2.25 & 2.44 & 2.38 & 0.15 \\
\hline $\mathrm{A}: \mathrm{P}$ & 2.76 & 2.86 & 2.87 & 2.86 & 0.18 \\
\hline $\mathrm{NH}_{3}-\mathrm{N}, \mathrm{mg} / \mathrm{dL}$ & 12.1 & 11.0 & 11.7 & 12.6 & 1.15 \\
\hline
\end{tabular}

${ }^{\mathrm{a}-\mathrm{c}}$ Means within a row with different superscripts differ $(P<0.05)$.

${ }^{1} \mathrm{CON}=$ control (no injection of recombinant bST or supplemental Val); rbST $=$ single injection of recombinant $\mathrm{bST} ; \mathrm{V} 40=40 \mathrm{~g} / \mathrm{d}$ of Val; V80 $=80 \mathrm{~g} / \mathrm{d}$ of Val. 


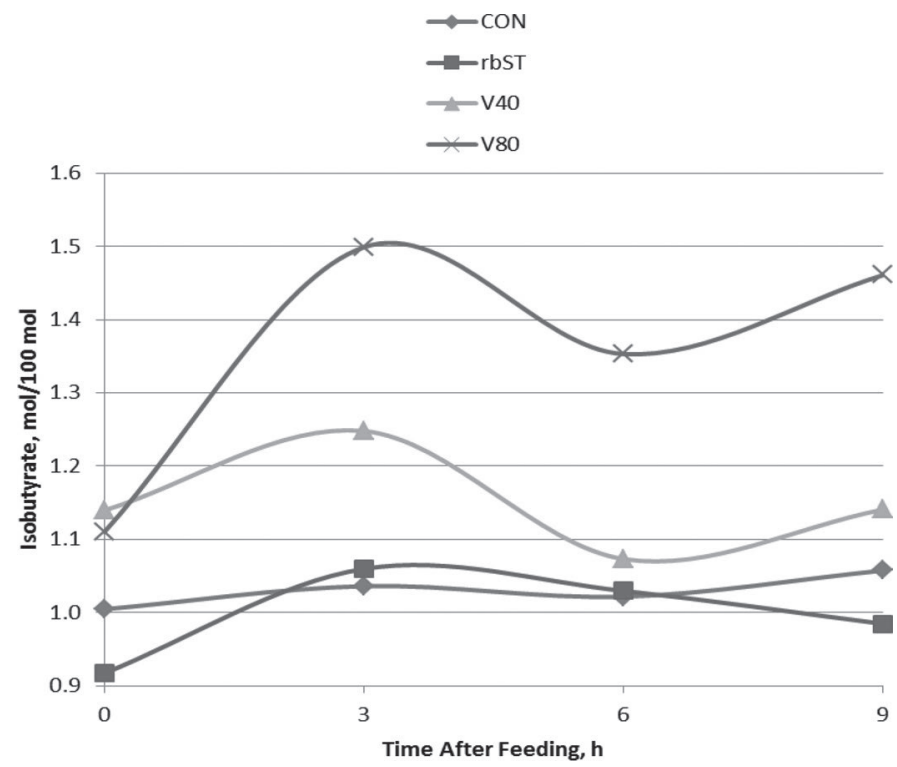

Figure 1. Rumen fluid concentrations of isobutyrate collected every $3 \mathrm{~h}$ from 0 to $9 \mathrm{~h}$ after feeding for late-lactating dairy cows. CON $=$ control (no injection of recombinant bST or supplemental Val); $\mathrm{rbST}=$ single injection of recombinant bST; V $40=40 \mathrm{~g} / \mathrm{d}$ of Val; V80 $=80 \mathrm{~g} / \mathrm{d}$ of Val. SEM $=0.05$; treatment $=P<0.01 ;$ time $=P<0.01$; treatment $\times$ time $=P<0.01$.

tended $(0.05 \leq P<0.10)$ to have increased NEFA concentrations compared with cows receiving V40.

Growth hormone concentrations were increased $(P$ $<0.05)$ for cow receiving $\mathrm{rbST}$ compared with cows receiving V40 and V80, with CON cows being intermediate and similar $(P \geq 0.10$; Table 8$)$. Insulin-like growth factor-1 concentrations were increased $(P<$ 0.05) for cows receiving rbST when compared with cows receiving V40 and V80, with cows receiving V80 having less $(P<0.05)$ than cows receiving V40, and CON cows being intermediate and similar $(P \geq 0.10)$ between cows receiving V40 and V80. Growth hormone concentrations tended to vary more throughout the day than did IGF-1 concentrations (Figures 2 and 3), but in general rbST-treated cows had the highest concentrations of GH and IGF-1 from 0 to $9 \mathrm{~h}$ after feeding.

\section{DISCUSSION}

\section{Nutrient Composition of the Diet}

The nutrient composition of the TMR is adequate to meet the requirements of late-lactating Holstein dairy cows (NRC, 2001). The NRC (2001) recommends that lactating, large-breed dairy cows at 90 DIM or greater producing $35 \mathrm{~kg} / \mathrm{d}$ of milk with $3.5 \%$ milk fat and $3.0 \%$ milk protein consume a diet with $15.1 \% \mathrm{CP}, 1.47 \mathrm{Mcal} /$ $\mathrm{kg}$ of $\mathrm{NE}_{\mathrm{L}}, 25$ to $33 \% \mathrm{NDF}, 17$ to $21 \% \mathrm{ADF}$, and 36 to $44 \%$ NFC. The reason for having a TMR with a high $\mathrm{CP}$ value in our study was to minimize the risk of obtaining a milk production response due to a protein deficiency. The $\mathrm{NE}_{\mathrm{L}}$ was kept high in the current study to maximize response in milk production to treatments. Neutral detergent fiber, ADF, and NFC were all within normal guidelines as given in the NRC (2001). One way that the $\mathrm{CP}$ amount in the diet was increased was by providing a high-quality alfalfa haylage with a relative forage quality of 178 , which indicates that this forage was adequate in providing the required nutrients to a dairy cow in late lactation (Jeranyama and Garcia, 2004 ) and also was high in CP at $23.7 \%$ DM (NRC, 2001), which helped boost the overall CP of the TMR.

\section{Milk Production, Composition, and Quality}

Our study confirms the hypothesis that feeding rumen-degradable Val will increase milk production to similar amounts achieved with recombinant bST. The increase in milk production was $\geq 2.9 \mathrm{~kg} / \mathrm{d}$ when cows were fed V40 or V80 compared with cows fed the CON. The milk production increase observed when feeding Val was comparable to the increase in milk production observed with a single injection of recombinant bST, suggesting that Val may be a viable option for dairy producers to increase milk production without using recombinant bST. Similarly, Liu et al. (2009) also found an increase in milk production when supplementing isobutyrate, the end product of oxidative deamination and decarboxylation of Val in the rumen, and found an increase in milk production of $2.2 \mathrm{~kg} / \mathrm{d}$ compared with cows not supplemented with isobutyrate.

The current study also found an increase in milk fat and milk protein yields for cows receiving V40 compared with cows receiving $\mathrm{CON}$, which led to increases in $3.5 \% \mathrm{FCM}$ and ECM for cows receiving either Val treatment. In comparison, Liu et al. (2009) found a decrease in milk fat and milk protein yields. This may have occurred due to inadequate nutrient supply, which was averted with the higher ration nutrient concentrations in our study. This increase in components observed in the current study will benefit the producer's milk profits and allow the producer to gain a higher premium. The decrease in SNF for cows receiving rbST compared with cows receiving CON would lead to decreased premiums; whereas Val-treated cows were intermediate and similar, leading to no decrease in SNF premiums. Rook and Line (1961) stated that an increase in the plane of energy nutrition of the cow can lead to increases in milk yield and SNF, but will lead to a decrease in milk fat content, which will have little to no effect on milk fat yield. This is similar to the results found in our study for cows receiving Val treatments. 
Table 6. Rumen fluid concentrations of VFA collected every $3 \mathrm{~h}$ from 0 to $9 \mathrm{~h}$ after feeding from late-lactating dairy cows on d 6 of the experimental period

\begin{tabular}{|c|c|c|c|c|c|c|c|c|}
\hline \multirow[b]{2}{*}{ Measurement } & \multicolumn{4}{|c|}{ Treatment $(\mathrm{T})^{1}$} & \multirow[b]{2}{*}{ SEM } & \multicolumn{3}{|c|}{$P$-value } \\
\hline & $\mathrm{CON}$ & rbST & $\mathrm{V} 40$ & V80 & & $\mathrm{T}$ & Time & $\mathrm{T} \times$ Time \\
\hline $0 \mathrm{~h}$ & 79.1 & 74.8 & 80.8 & 78.0 & 7.44 & 0.98 & 0.09 & 0.97 \\
\hline $3 \mathrm{~h}$ & 84.5 & 87.6 & 86.8 & 82.7 & 7.44 & 0.98 & 0.09 & 0.97 \\
\hline $6 \mathrm{~h}$ & 82.8 & 86.5 & 77.2 & 77.9 & 7.44 & 0.98 & 0.09 & 0.97 \\
\hline $9 \mathrm{~h}$ & 90.9 & 87.0 & 85.7 & 92.8 & 7.44 & 0.98 & 0.09 & 0.97 \\
\hline $0 \mathrm{~h}$ & 62.8 & 62.3 & 62.3 & 63.9 & 1.46 & 0.45 & $<0.01$ & 0.94 \\
\hline $3 \mathrm{~h}$ & 62.1 & 61.0 & 60.6 & 61.4 & 1.46 & 0.45 & $<0.01$ & 0.94 \\
\hline $6 \mathrm{~h}$ & 60.8 & 60.0 & 61.1 & 61.2 & 1.46 & 0.45 & $<0.01$ & 0.94 \\
\hline $9 \mathrm{~h}$ & 61.1 & 59.7 & 60.9 & 60.3 & 1.46 & 0.45 & $<0.01$ & 0.94 \\
\hline \multicolumn{9}{|l|}{ Propionate } \\
\hline $0 \mathrm{~h}$ & 21.4 & 22.3 & 21.6 & 20.4 & 1.75 & 0.57 & $<0.01$ & 0.91 \\
\hline $3 \mathrm{~h}$ & 22.0 & 22.3 & 22.3 & 21.5 & 1.75 & 0.57 & $<0.01$ & 0.91 \\
\hline $6 \mathrm{~h}$ & $1.23^{\mathrm{c}}$ & $1.20^{\mathrm{c}}$ & $1.40^{\mathrm{b}}$ & $1.70^{\mathrm{a}}$ & 0.05 & $<0.01$ & $<0.01$ & $<0.01$ \\
\hline $9 \mathrm{~h}$ & $1.17^{\mathrm{c}}$ & $1.13^{\mathrm{c}}$ & $1.32^{\mathrm{b}}$ & $1.54^{\mathrm{a}}$ & 0.05 & $<0.01$ & $<0.01$ & $<0.01$ \\
\hline \multicolumn{9}{|l|}{ Butyrate } \\
\hline $0 \mathrm{~h}$ & 9.95 & 9.75 & 10.0 & 9.91 & 0.34 & 0.75 & 0.92 & 0.77 \\
\hline $3 \mathrm{~h}$ & 9.88 & 10.3 & 9.89 & 10.1 & 0.34 & 0.75 & 0.92 & 0.77 \\
\hline $6 \mathrm{~h}$ & 10.1 & 10.2 & 9.69 & 10.0 & 0.34 & 0.75 & 0.92 & 0.77 \\
\hline $9 \mathrm{~h}$ & 10.1 & 9.85 & 9.83 & 10.2 & 0.34 & 0.75 & 0.92 & 0.77 \\
\hline \multicolumn{9}{|l|}{ Isovalerate } \\
\hline $0 \mathrm{~h}$ & 2.81 & 2.66 & 2.74 & 2.73 & 0.19 & 0.89 & 0.03 & 0.20 \\
\hline $3 \mathrm{~h}$ & 2.67 & 2.78 & 2.96 & 2.78 & 0.19 & 0.89 & 0.03 & 0.20 \\
\hline $6 \mathrm{~h}$ & 2.82 & 2.74 & 2.52 & 2.52 & 0.19 & 0.89 & 0.03 & 0.20 \\
\hline $9 \mathrm{~h}$ & 2.70 & 2.59 & 2.56 & 2.52 & 0.19 & 0.89 & 0.03 & 0.20 \\
\hline \multicolumn{9}{|l|}{ Valerate } \\
\hline
\end{tabular}

${ }^{\mathrm{a}-\mathrm{c}}$ Means within a row with different superscripts differ $(P<0.05)$.

${ }^{1} \mathrm{CON}=$ control (no injection of recombinant bST or supplemental Val); rbST $=$ single injection of recombinant bST; V40 = $40 \mathrm{~g} / \mathrm{d}$ of Val; V80 $=80 \mathrm{~g} / \mathrm{d}$ of Val.

Table 7. Blood plasma concentrations of VFA, glucose, and NEFA collected $3 \mathrm{~h}$ after feeding from latelactating dairy cows

\begin{tabular}{lccccc}
\hline & \multicolumn{5}{c}{ Treatment $^{1}$} \\
\cline { 2 - 4 } Measurement & CON & rbST & V40 & V80 & SEM \\
\hline Total VFA, mM & $1.75^{\mathrm{ab}}$ & $1.61^{\mathrm{b}}$ & $1.78^{\mathrm{a}}$ & $1.77^{\mathrm{a}}$ & 0.09 \\
VFA, mol/100 mol & & & & & \\
Acetate (A) & $90.1^{\mathrm{b}}$ & $90.3^{\mathrm{ab}}$ & $90.1^{\mathrm{b}}$ & $91.0^{\mathrm{a}}$ & 0.63 \\
Propionate (P) & $4.71^{\mathrm{a}}$ & $4.33^{\mathrm{ab}}$ & $4.60^{\mathrm{ab}}$ & $4.19^{\mathrm{b}}$ & 0.30 \\
Isobutyrate & 1.33 & 1.37 & 1.30 & 1.22 & 0.13 \\
Butyrate & $2.62^{\mathrm{ab}}$ & $2.60^{\mathrm{ab}}$ & $2.67^{\mathrm{a}}$ & $2.39^{\mathrm{b}}$ & 0.18 \\
Isovalerate & 1.24 & 1.36 & 1.30 & 1.14 & 0.12 \\
A:P & 21.3 & 24.9 & 20.9 & 24.2 & 2.41 \\
Glucose, mg/dL & $51.2^{\mathrm{b}}$ & 49.8 & 51.5 & 50.2 & 3.44 \\
NEFA, $\mu \mathrm{Eq} / \mathrm{L}$ & $152^{\mathrm{b}}$ & $182^{\mathrm{a}}$ & $154^{\mathrm{ab}}$ & $154^{\mathrm{b}}$ & 9.11 \\
\hline
\end{tabular}

a,b Means within a row with different superscripts differ $(P<0.05)$.

${ }^{1} \mathrm{CON}=$ control (no injection of recombinant bST or supplemental Val); rbST $=$ single injection of recombinant $\mathrm{bST} ; \mathrm{V} 40=40 \mathrm{~g} / \mathrm{d}$ of Val; V80 $=80 \mathrm{~g} / \mathrm{d}$ of Val. 


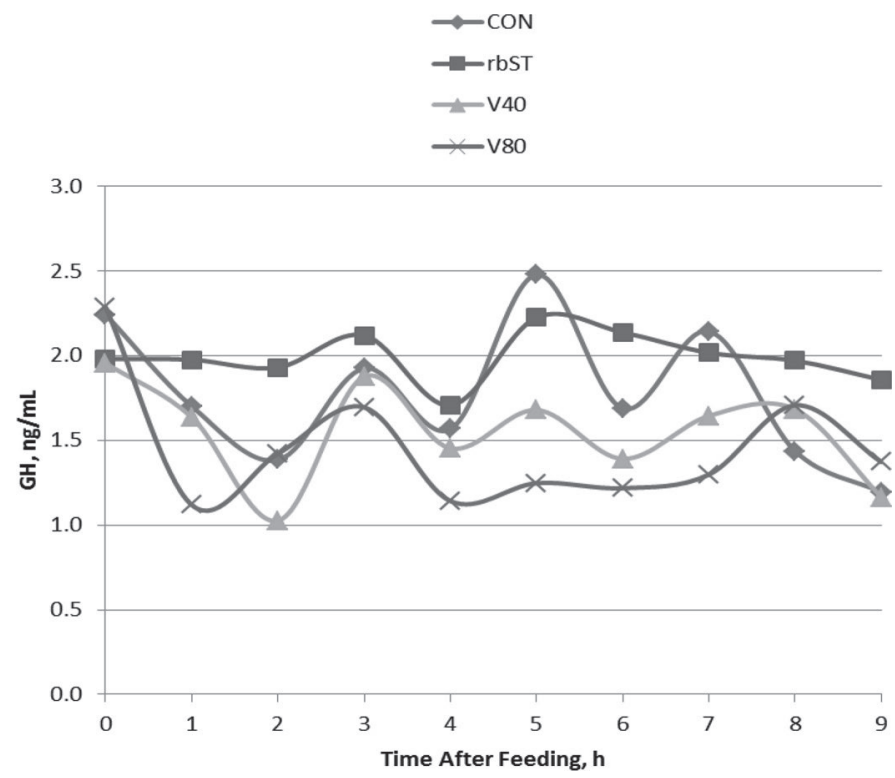

Figure 2. Blood plasma concentrations of growth hormone (GH) collected every hour from 0 to $9 \mathrm{~h}$ after feeding for late-lactating dairy cows. CON $=$ control (no injection of recombinant bST or supplemental Val); rbST $=$ single injection of recombinant bST; V40 $=40 \mathrm{~g} / \mathrm{d}$ of Val; V80 $=80 \mathrm{~g} / \mathrm{d}$ of Val. SEM $=0.32$; treatment $=P<0.01 ;$ time $=$ $P<0.01$; treatment $\times$ time $=P=0.25$.

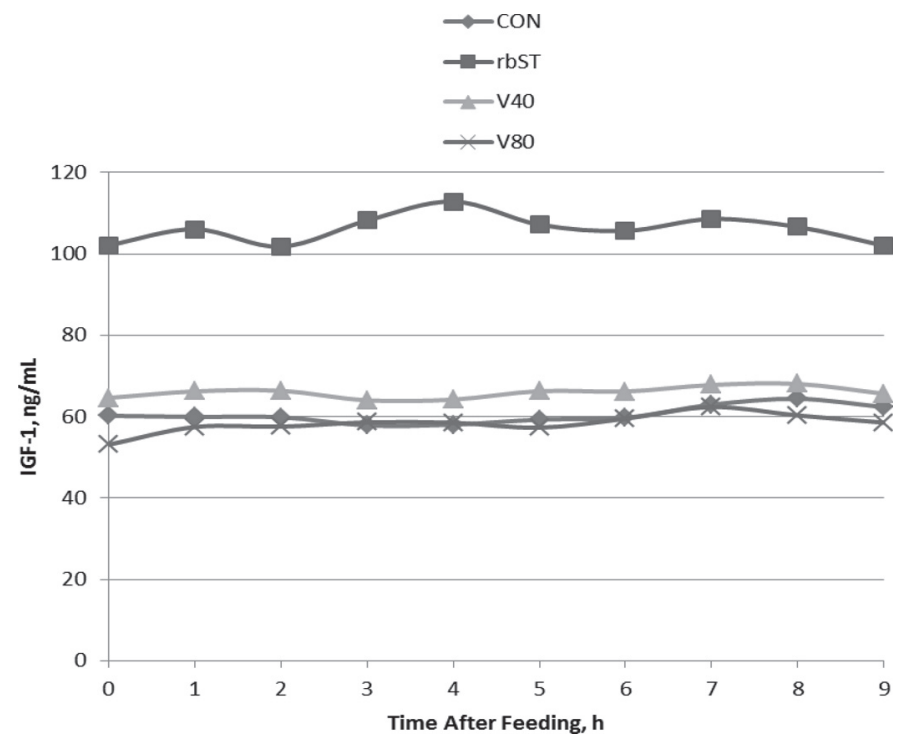

Figure 3. Blood plasma concentrations of IGF-1 collected every hour from 0 to $9 \mathrm{~h}$ after feeding for late-lactating dairy cows. CON = control (no injection of recombinant bST or supplemental Val); rbST $=$ single injection of recombinant bST; V40 $=40 \mathrm{~g} / \mathrm{d}$ of Val; V80 $=$ $80 \mathrm{~g} / \mathrm{d}$ of Val. SEM $=5.62 ;$ treatment $=P<0.01 ;$ time $=P=0.41$; treatment $\times$ time $=P=0.99$.

Table 8. Blood plasma concentrations of growth hormone (GH) and IGF-1 collected every hour from 0 to 9 h after feeding from late-lactating dairy cows on $\mathrm{d} 6$ of the experimental period

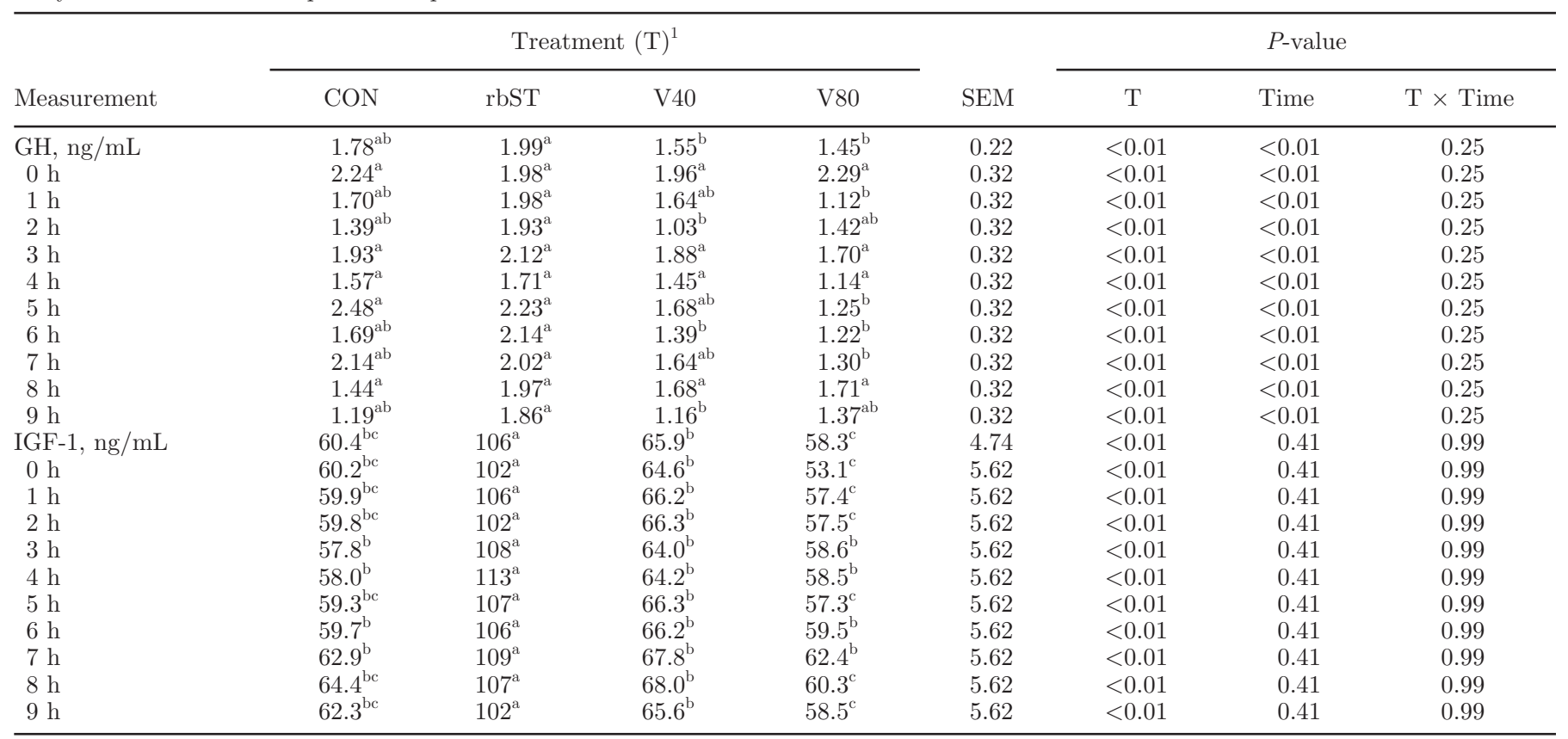

${ }^{a-c}$ Means within a row with different superscripts differ $(P<0.05)$.

${ }^{1} \mathrm{CON}=$ control (no injection of recombinant bST or supplemental Val); rbST = single injection of recombinant bST; V40 = $40 \mathrm{~g} / \mathrm{d}$ of Val; V80 $=80 \mathrm{~g} / \mathrm{d}$ of Val. 
Walstra et al. (1984) stated that the average milk lactose content is $4.60 \%$, which is very similar to the current study average of $4.59 \%$ for all treatments. Thomas and Chamberlain (1984) stated that lactose is the most constant component of milk because lactose's main role is to maintain osmotic content. The increase in MUN with the Val treatments may be attributed to the deamination of Val in the rumen to isobutyric acid (Rosener and Uhlenhopp, 1987), but these MUN values still fall within the recommended range of 10 to $14 \mathrm{mg} /$ dL (Ferguson, 2000).

Somatic cell scores were similar among treatments, which indicates that cows treated with rbST or supplemented with Val were at no additional risk for mastitis. Although no differences in SCS were noted between treatments, the SCS did tend to be high, with an average SCS of 4.60 for all treatments, even though cows at the end of lactation would be expected to be higher in SCS than early-lactation cows (Dulin et al., 1983). According to Ruegg (2001), an SCS of 4 leads to a milk production loss of $360 \mathrm{~kg}$ per lactation for multiparous cows.

\section{$D M I$ and FE}

The decrease in DMI observed when increasing Val from 40 to $80 \mathrm{~g} / \mathrm{d}$ may be due to a palatability issue, an unknown effect of isobutyrate metabolism having a negative feedback on DMI, or an unknown metabolic effect of improving FE. However, palatability issues in the field would not be expected because our study demonstrated no improvements in milk production when increasing Val from 40 to $80 \mathrm{~g} / \mathrm{d}$, so the recommended feeding amount of Val would be no more than $40 \mathrm{~g} / \mathrm{d}$. The decrease in DMI may also be due to the increase in isobutyrate in the rumen fluid, which led to increased efficiency of metabolism (Papas et al., 1984) and, therefore, decreased DMI. Due to the decrease in DMI for cows receiving V80, a significant increase in $\mathrm{FE}$ was observed for cows receiving V80 compared with CON cows, but no significant differences in $\mathrm{FE}$ were noted for cows receiving V40 compared with CON cows. Although FE was improved for cows receiving V80, more research is needed to determine the long-term effects of Val on DMI.

\section{$B W$ and BCS}

Body weights were increased for cows receiving rbST and V40 compared with CON cows; however, BCS remained similar among treatments and remained within normal ranges of 3.25 to 3.75 for late-lactating dairy cows (Kellogg, 2015). Sakaguchi (2009) stated that
BCS is a more accurate way of determining reproductive performance; therefore, cows supplemented with Val may have increased slightly in BW, but were not putting on excessive fat that may hinder their reproductive performances. Longer-term studies would be needed to confirm or refute these observations.

\section{Rumen Fluid Analysis}

The treatments in our study resulted in no changes in acetate or propionate concentrations, which led to similar acetate-to propionate-ratios among treatments. In contrast, Liu et al. (2009) found a linear increase in acetate and a linear decrease in propionate as supplementation of isobutyrate increased, which led to an increased acetate-to-propionate ratio for the isobutyrate treatments. The differences between our study and Liu et al. (2009) could be due to rumen adaptation time and or ration nutrient composition. In the study conducted by Liu et al. (2009), each period lasted 28 $\mathrm{d}$ versus the 21-d periods in the current study, which would have allowed rumen microbes more time to adjust to the different treatments.

Although there were no significant changes in acetate or propionate concentrations, an increase in isobutyrate concentrations was noted in the rumen as Val supplementation increased in the diet. This can be attributed to the oxidative deamination and decarboxylation of Val to isobutyric acid in the rumen (Rosener and Uhlenhopp, 1987). This observation would confirm our hypothesis of feeding a rumen-degradable AA, Val, to increase the ruminal supply of isobutyrate without having an objectionable odor. Even though isobutyrate concentrations increased in the rumen, total VFA concentrations remained similar among treatments. This could be due to the low concentration of isobutyrate in the rumen compared with other VFA, which would result in a smaller effect on total VFA concentrations. In the current study, isobutyrate made up just over $1 \%$ of the total VFA concentration in the rumen. Also, our hypothesis was that isobutyric acid would be absorbed across the rumen wall thereby maintaining isobutyrate concentrations within normal ranges.

The $\mathrm{pH}$ remained similar among treatments and within the optimum range for cellulolytic bacterial activity (Russell and Wilson, 1996). The rumen fluid concentrations of $\mathrm{NH}_{3}-\mathrm{N}$ were not affected by treatment and remained similar to $\mathrm{NH}_{3}-\mathrm{N}$ concentrations found by Liu et al. (2009). We expected $\mathrm{NH}_{3}-\mathrm{N}$ concentrations to increase with supplemental Val due to the deamination of Val in the rumen fluid, especially because increases in isobutyrate concentration were observed in rumen fluid for cows receiving Val. These results could again 
be due to a lack of adaptation time of rumen microbes or the amount of Val added to the diet may not have been enough to observe an increase in $\mathrm{NH}_{3}-\mathrm{N}$.

\section{Blood Analysis}

The increase in acetate concentrations in blood plasma for cows receiving V80 compared with CON cows may be attributed to the increase in fiber digestion observed with increased isobutyrate in the rumen (Papas et al., 1984), as acetate is the major VFA produced by fiber-digesting bacteria (Church, 1988), although we did not observe an increase in acetate in the rumen fluid for cows receiving V80. Due to the increase in blood plasma acetate concentrations for cows receiving V80 this led to a decrease in blood plasma propionate concentrations, which is the major VFA produced by starch-digesting bacteria (Church, 1988).

Glucose is important to milk production with 60 to $80 \%$ of glucose turnover used for milk production (Etherton and Bauman, 1998); therefore, it is important to maintain adequate glucose concentrations in the blood. Our study reports similar blood glucose concentrations for cows receiving all treatments, indicating that all animals had sufficient blood glucose concentrations to produce the observed amount of milk. Glucose is also important in lactose synthesis, with $85 \%$ of the carbon secreted in lactose derived from blood glucose (Bickerstaffe et al., 1974), but no differences in glucose among treatments were observed, which led to similar milk lactose concentrations among treatments.

Blood plasma concentrations of NEFA were increased significantly or tended to increase for cows receiving rbST compared with cows receiving the other treatments. An increase in NEFA concentrations could indicate that these cows were mobilizing body fat to meet the energy needs for the additional milk production by cows receiving rbST compared with cows receiving the other treatments. In addition, it takes time for cows to respond with increasing DMI to meet the increase nutrient demands of enhanced milk production. No treatment resulted in NEFA concentrations being $\geq 0.5$ $\mathrm{mEq} / \mathrm{L}$, which has been shown to increase the risk of a left displaced abomasum (LeBlanc et al., 2005) or could be regarded as subclinical ketosis.

Although milk production increased when feeding Val, no increases in plasma GH concentrations were observed when feeding Val as hypothesized in our model. As no increases in GH were noted, an increase in IGF-1 was not observed because IGF-1 is secreted by the liver and its release is stimulated by the release of $\mathrm{GH}$ from the anterior pituitary (Laron, 2001). Although the lactational performance results reported confirm the hy- pothesis, the exact mechanism is still to be elucidated; but several hypotheses are plausible: (1) the increase in milk production was produced by a different mechanism than hypothesized, (2) the response of isobutyrate enhancing $\mathrm{GH}$ release may be more subtle than administering recombinant bST, (3) the increase in GH may have been missed because blood GH concentrations were only measured 9 out of the $24 \mathrm{~h}$ during $1 \mathrm{~d}$ each period, and (4) isobutyrate concentrations could be enhancing the half-life of IGF-1 by increasing the number of IGF binding proteins or the affinity of IGF-1 for IGF binding proteins. Additional work is warranted to elucidate the mechanism of isobutyrate enhancing milk production.

\section{Cost Analysis}

The cost of one 14-d dose of Posilac is approximately $\$ 7.30$, which equates to $\$ 0.52 / \mathrm{d}$ (Elanco, 2014). In contrast, the cost of L-Val is $\$ 16.50 / \mathrm{kg}$ or $\$ 0.66 / \mathrm{d}$ when fed at $40 \mathrm{~g} / \mathrm{d}$ (Ajinomoto sales representative, personal communication). These costs may vary depending on where the producer obtains these products and if they can be purchased in bulk. Our study reports that increasing Val from 40 to $80 \mathrm{~g} / \mathrm{d}$ had no additional benefits on milk production. Although Posilac is cheaper than feeding Val at $40 \mathrm{~g} / \mathrm{d}$, the profitability of Val is still present with an average increase in milk production of $3.1 \mathrm{~kg} / \mathrm{d}$ for both Val treatments at a price of $\$ 0.36 / \mathrm{kg}$ of milk (USDA, 2015), resulting in a return on investment of 1.7:1; however, if it can be determined in future studies that feeding less than $40 \mathrm{~g} / \mathrm{d}$ of Val can have the same effect on milk production, the feeding cost of Val would decrease on a cow per day basis and the return on investment would improve to meet or exceed the return on investment of recombinant bST.

\section{CONCLUSIONS}

This study confirms that supplementation of the synthetic rumen-degradable AA, Val, can increase milk production similar to increases in milk production with the use of recombinant bST, but the lack of response in blood plasma GH or IGF-1 concentrations is unknown. Therefore, the exact mechanism that resulted in the increase in milk production is still to be elucidated. This study also demonstrated that the feeding rate of Val above $40 \mathrm{~g} / \mathrm{d}$ resulted in no additional benefits in milk production. More research needs to be conducted to elucidate the exact mechanism behind the increase in milk production observed when supplementing Val, but if this mechanism is determined, feeding Val to lactating dairy cows could be a viable replacement to 
recombinant bST for those dairy producers that cannot use recombinant bST due to consumer requests.

\section{ACKNOWLEDGMENTS}

The authors express appreciation to the staff at the South Dakota State University Dairy Research and Training Facility (Brookings, SD) for the feeding and care of the animals, the graduate students at South Dakota State University for assistance in sample collection and analyses, and Michele Mucciante (South Dakota State University) for training and assistance in placing catheters. This research was funded by the Women and Giving Fund and the South Dakota Agricultural Experiment Station (Brookings).

\section{REFERENCES}

Alpkem Corporation. 1990. RFA Methodology. A303-S620. Alpkem Corp., Clackamas, OR.

Anderson, M. 1982. Factors affecting the distribution of lipoprotein lipase activity between serum micelles in bovine milk. J. Dairy Res. 49:51-59.

AOAC International. 1998. Official Methods of Analysis. 16th ed. AOAC International, Gaithersburg, MD.

AOAC International. 2002. Official Methods of Analysis. 18th ed. AOAC International, Gaithersburg, MD.

Bickerstaffe, E. N., E. F. Annison, and J. L. Linzell. 1974. The metabolism of glucose, acetate, lipids and amino acids in lactating dairy cows. J. Agric. Sci. 82:71-85.

Cancalon, P. F. 1993. Rapid monitoring of fruit juice adulteration by capillary electrophoresis. Liquid Chromatography Gas Chromatography 11:748-751.

Capper, J. L., E. Castañeda-Gutiérrez, R. A. Cady, and D. E. Bauman. 2008. The environmental impact of recombinant bovine somatotropin (rbST) use in dairy production. Proc. Natl. Acad. Sci. USA 105:9668-9673.

Chaney, A. L., and E. P. Marbach. 1962. Modified reagents for determination of urea and ammonia. Clin. Chem. 8:130-132.

Church, D. C. 1988. The Ruminant Animal: Digestive Physiology and Nutrition. Prentice-Hall, Inc. Englewood Cliffs, N.J.

Dairy Herd Management. 2015. McDonald's will source only non-rBST cows' milk, antibiotic free chicken. Accessed Apr. 23, 2015. http:// www.dairyherd.com/news/mcdonalds-will-source-only-non-rbstcows-milk-antibiotic-free-chicken.

Damon, C. 1966. Hawk's Physiological Chemistry. 14th ed. McGrawHill, New York, NY.

Daughaday, W. H., I. K. Mariz, and S. L. Blethen. 1980. Inhibition of access of bound somatomedin to membrane receptor and immunobinding sites: A comparison of radioreceptor and radioimmunoassay of somatomedin in native and acid-ethanol-extracted serum. J. Clin. Endocrinol. Metab. 51:781-788.

Dulin, A. M., M. J. Paape, W. D. Schultze, and B. T. Weinland. 1983. Effect of parity, stage of lactation, and intramammary infection on concentration of somatic cells and cytoplasmic particles in goat milk. J. Dairy Sci. 66:2426-2433

Echternkamp, S. E., L. J. Spicer, K. E. Gregory, S. F. Canning, and J. M. Hammond. 1990. Concentrations of insulin-like growth factor-I in blood and ovarian follicular fluid of cattle selected for twins. Biol. Reprod. 43:8-14.

El Rassi, Z. 1996. High Performance Capillary Electrophoresis of Carbohydrates. Beckman Instruments, Inc., Fullerton, CA.

Elanco. 2014. Posilac. Elanco Animal Health, Greenfield, IN. Accessed April 23, 2015. http://www.elanco.us/products-services/dairy/ posilac/\#product.
Erwin, E. S., G. J. Marco, and E. M. Emery. 1961. Volatile fatty acid analysis of blood and rumen fluid by gas chromatography. J. Dairy Sci. 44:1768-1771.

Etherton, T. D., and D. E. Bauman. 1998. Biology of somatotropin in growth and lactation of domestic animals. Physiol. Rev. 78:745761.

Ferguson, J. D. 2000. Milk Urea Nitrogen. Center for Animal Health and Productivity, University of Pennsylvania, Kenneth Square, PA.

Funston, R. N., G. E. Moss, and A. J. Roberts. 1995. Insulin-like growth factor-I (IGF-I) and IGF-binding proteins in bovine sera and pituitaries at different stages of the estrous cycle. Endocrinology $136: 62-68$.

ISO. 2013. Water quality-Determination of ammonium nitrogenMethod by flow analysis (CFA and FIA) and spectrometric detection. International Organization of Standardization (ISO), Geneva, Switzerland.

Jeranyama, P., and A. D. Garcia. 2004. Understanding relative feed value (RFV) and relative forage quality (RFQ), Cooperative Extension Service, College of Agricultural and Biological Sciences, South Dakota State University. Accessed Jun. 15, 2015. http:// pubstorage.sdstate.edu/AgBio_Publications/articles/exex8149. pdf.

Kellogg, W. 2015. Body Condition Scoring with Dairy Cattle. Division of Agriculture, University of Arkansas, Fayetteville, AR. Accessed Jun. 15, 2015. https://www.uaex.edu/publications/PDF/ FSA-4008.pdf.

Klindt, J., J. J. Ford, J. G. Berardinelli, and L. L. Anderson. 1983. Growth hormone secretion after hypophysial stalk transection in pigs. Proc. Soc. Exp. Biol. Med. 172:508-513.

Krishnamoorthy, U., T. V. Muscato, C. J. Sniffen, and P. J. Van Soest. 1982. Nitrogen fractions in selected feedstuffs. J. Dairy Sci 65:217-225.

Kung, L. Jr., and L. M. Rode. 1996. Amino acid metabolism in ruminants. Anim. Feed Sci. Technol. 59:167-172.

Laron, Z. 2001. Insulin-like growth factor 1 (IFG-1): A growth hormone. Mol. Pathol. 54:311-316.

LeBlanc, S. J., K. E. Leslie, and T. F. Duffield. 2005. Metabolic predictors of displaced abomasum in dairy cattle. J. Dairy Sci. $88: 159-170$

Liu, Q., C. Wang, W. Z. Yang, B. Zhang, X. M. Yang, D. C. He, P. Zhang, K. H. Dong, and Y. X. Huang. 2009. Effects of isobutyrate on rumen fermentation, lactation performance and plasma characteristics in dairy cows. Anim. Feed Sci. Technol. 154:58-67.

Marten, G. C., and R. F. Barnes. 1980, Prediction of energy digestibility of forages with in vitro rumen fermentation and fungal enzyme systems. Pages 61-71 in Standardiztion of Analytical Methodology for Feeds: Proceedings of a Workshop held in Ottawa, Canada. March 12-14, 1979. IDRC Ottawa, Canada.

National Center for Biotechnology Information. 2015. Isobutyric acid. Accessed Apr. 25, 2015. http://pubchem.ncbi.nlm.nih.gov/ compound/isobutyric_acid\#section=Top.

NRC. 2001. Nutrient Requirements of Dairy Cattle. 7th rev. ed. Natl. Acad. Press, Washington, DC.

Oba, M., and M. S. Allen. 2003. Effects of corn grain conservation method on feeding behavior and productivity of lactating dairy cows at two dietary starch concentrations. J. Dairy Sci. 86:174183.

Organic Consumers Association. 2007. Starbucks agrees to ban Monsanto's bovine growth hormone from all its cafes by end of year. Organic Consumers Association, Finland, MN

Orth, R. 1992. Sample day and lactation report. DHIA 200 Fact Sheet A-2. Mid-States Dairy Records Processing Center, Ames, IA.

Ozhikandathil, J., S. Badilescu, and M. Packirisamy. 2014. A portable on-chip assay system for absorbance and plasmonic detection of recombinant bovine growth hormone in milk. J. Dairy Sci. (Article in Press).

Papas, A. M., S. R. Ames, R. M. Cook, C. J. Sniffen, C. E. Polan, and L. Chase. 1984. Production responses of dairy cows fed diets supplemented with ammonium salts of iso C-4 and C-5 acids. J. Dairy Sci. 67:276-293. 
Peirce-Sandner, S. B., A. M. Papas, J. A. Rogers, T. F. Sweeney, K. A. Cummins, H. R. Conrad, and L. D. Muller. 1985. Supplementation of dairy cows diets with ammonium salts of volatile fatty acids. J. Dairy Sci. 68:2895-2907.

Rohweder, D. A., R. F. Barnes, and N. Jorgensen. 1978. Proposed hay grading standards based on laboratory analyses for evaluating quality. J. Anim. Sci. 47:747-759.

Rook, J. A. F., and C. Line. 1961. The effect of the plane of energy nutrition of the cow on the secretion in milk of the constituents of the solids-not-fat fraction and on the concentrations of certain blood-plasma constituents. Br. J. Nutr. 15:109-119.

Rosener, D. L., and E. K. Uhlenhopp. 1987. Isoacids-An overview. Iowa State Univ. Vet. 49:15-20.

Ruegg, P. L. 2001. Milk Secretion and Quality Standards. University of Wisconsin, Madison.

Russell, J. B., and D. B. Wilson. 1996. Why are ruminal cellulolytic bacteria unable to digest cellulose at low pH. J. Dairy Sci. 79:1503-1509.

Sakaguchi, M. 2009. Differences between body condition scores and body weight changes in postpartum dairy cows in relation to parity and reproductive indices. Can. Vet. J. 50:649-656.

Schroeder, J. W. 2012. Bovine Mastitis and Milking Management. AS1129. North Dakota State University Extension Service, Fargo.
Thomas, P. C., and D. G. Chamberlain. 1984. Manipulation of Milk Composition to Meet Market Needs. Recent Advances in Animal Nutrition, Butler and Tanner Ltd., Frome, Somerset, UK.

US Environmental Protection Agency (EPA). 1993. Determination of total Kjeldahl nitrogen by semi-automated colorimetry. EPA Office of Research and Development, Cincinnati, $\mathrm{OH}$.

USDA. 2015. Announcement of advanced prices and pricing factors. Accessed Jun. 15, 2015. http://www.ams.usda.gov/AMSv1.0/getfi le?dDocName=STELPRD3247515.

Van Soest, P. J., J. B. Robertson, and B. A. Lewis. 1991. Methods for dietary fiber, neutral detergent fiber, and nonstarch polysaccharides in relation to animal nutrition. J. Dairy Sci. 74:3583-3597.

Walstra, P., R. Jenness, and H. T. Badings. 1984. Dairy Chemistry and Physics. John Wiley and Sons, Inc., Hoboken, NJ.

Wildman, E. E., G. M. Jones, P. E. Wagner, and R. L. Boman. 1982 A dairy cow body condition scoring system and its relationship to selected production characteristic. J. Dairy Sci. 65:495-501.

Zanton, G. I., G. R. Bowman, M. Vazquez-Anon, and L. M. Rode. 2014. Meta-analysis of lactation performance in dairy cows receiving supplemental dietary methionine sources or postruminal infusion of methionine. J. Dairy Sci. 97:7085-7101. 